\title{
Phylogenetic analyses of Cladophora vagabunda (L.) C. Hoek (Cladophorales, Chlorophyta) from Brazil based on SSU rDNA sequences ${ }^{1}$
}

\author{
LÍSIA MÔNICA DE SOUZA GESTINARI², MARIANA CABRAL DE OLIVEIRA ${ }^{3,6}$, DANIELA \\ MILSTEIN $^{3}$, YOCIE YONESHIGUE-VALENTIN ${ }^{4}$ and SONIA MARIA BARRETO PEREIRA ${ }^{5}$
}

(received: May 20, 2008; accepted: June 10, 2009)

\begin{abstract}
Phylogenetic analyses of Cladophora vagabunda (L.) C. Hoek (Cladophorales, Chlorophyta) from Brazil based on SSU rDNA sequences). The complete SSU rDNA was sequenced for 10 individuals of Cladophora vagabunda collected along the coast of Brazil. For C. rupestris (L.) Kütz. a partial SSU rDNA sequence (1634 bp) was obtained. Phylogenetic trees indicate that Cladophora is paraphyletic, but the section Glomeratae sensu lato including C. vagabunda from Brazil, Japan and France, C. albida (Nees) Kütz., C. sericea (Hudson) Kütz., and C. glomerata (L.) Kütz. is monophyletic. Within this group C. vagabunda is paraphyletic. The sequence identity for the SSU rDNA varied from $98.9 \%$ to $100 \%$ for the Brazilian C. vagabunda, and from 98.3\% to 99.7\% comparing the Brazilian individuals to the ones from France and Japan. Sequence identity of the Brazilian $C$. vagabunda to C. albida and C. sericea vary from $98.0 \%$ to $98.6 \%$. The SSU rDNA phylogeny support partially the morphological characteristics presented by Brazilian populations of $C$. vagabunda. On the other hand, C. rupestris from Brazil does not group with $C$. rupestris from France, both sequences presenting only $96.9 \%$ of identity. The inclusion of sequences of individuals from Brazil reinforces the need of taxonomical revision for the genus Cladophora and for the complex C. vagabunda.
\end{abstract}

Key words - Brazil, Cladophora vagabunda, Cladophorales, molecular phylogeny, SSU rDNA

RESUMO - (Análises filogenéticas de Cladophora vagabunda (L.) C. Hoek (Cladophorales, Chlorophyta) do Brasil, baseada nas seqüências SSU rDNA). A seqüência completa do SSU rDNA foi obtida para 10 indivíduos de Cladophora vagabunda coletadas ao longo da costa do Brasil. Uma seqüência parcial do SSU rDNA (1634 bp) foi obtida para C. rupestris (L.) Kütz. As árvores filogenéticas indicam que Cladophora é parafilético, mas a seção Glomeratae sensu lato compreendendo C. vagabunda do Brasil, Japão e França, C. albida (Nees) Kütz., C. sericea (Hudson) Kütz. e C. glomerata (L.) Kütz., é monofilética. Dentro deste grupo, C. vagabunda é parafilética. A identidade da seqüência para o SSU rDNA variou de 98,9\% à $100 \%$ para C. vagabunda brasileira e de $98,3 \%$ a 99,7\% quando comparados os indivíduos brasileiros aos da França e do Japão. A identidade da seqüência entre $C$. vagabunda brasileira e as duas outras espécies (C. albida e $C$. sericea) variou entre 98,0\% e 98,6\%. A filogenia do SSU rDNA suporta parcialmente as caracteristícas morfológicas apresentadas pelas populações brasileiras de C. vagabunda. Por outro lado, C. rupestris do Brasil não se agrupou a C. rupestris da França, as duas seqüências apresentaram somente $96,9 \%$ de identidade. A inclusão de seqüências de indivíduos do Brasil reforçam a necessidade de uma revisão taxonômica para o gênero Cladophora e para o complexo C. vagabunda.

Palavras chave - Brasil, Cladophora vagabunda, Cladophorales, filogenia molecular, SSU rDNA

\section{Introduction}

The genus Cladophora Kütz. (Cladophorales, Chlorophyta) is composed by a heterogeneous group of species that shows a high morphological plasticity

1. Part of PhD Thesis of the first author - Programa de Pós-Graduação em Botânica, UFRPE, Brazil.

2. Universidade Federal do Rio de Janeiro, Núcleo em Ecologia e Desenvolvimento Sócio-Ambiental de Macaé (Nupem), Caixa Postal 119331, 27910-970 Macaé, Rio de Janeiro, RJ, Brazil.

3. Universidade de São Paulo, Instituto de Biociências, Departamento de Botânica, R. do Matão 277, 05508-900 São Paulo, SP, Brazil.

4. Universidade Federal do Rio de Janeiro, Instituto de Biologia, Departamento de Botânica, R. Prof. Rodolpho P. Rocco, s/nº, Ilha do Fundão, 21949-900 Rio de Janeiro, RJ, Brazil.

5. Universidade Federal Rural de Pernambuco, Departamento de Biologia, R. Dom Manoel de Medeiros, s/nº, Dois Irmãos, 52171900 Recife, Pernambuco, PE, Brazil.

6. Corresponding author: mcdolive@ib.usp.br influenced by thallus age and habitat. The genus is widespread in marine, freshwater, estuarine and brackish water environments, from temperate to tropical regions (Hoek 1963, 1982, Dodds \& Gudder 1992, Hoek et al. 1995, Hoek \& Chihara 2000, Leliaert et al. 2003). Taxonomical problems due to morphological plasticity and wide geographical distribution led to the use of molecular biology analyses to study the genus.

Bot et al. (1989a,b, 1990, 1991) estimated the genetic distance among individuals of Cladophora species with wide geographic disjunction, using the single strand complementary DNA-DNA hybridization. Unexpected wide genetic distances were observed between North Atlantic and Indo-Pacific individuals of C. albida (Nees) Kütz., corresponding to distances found among higher plants genera and mammals families. On the other hand, no divergence was found among $C$. sericea (Hudson) 
Kütz. amphiatlantic individuals, interpreted as result of a transatlantic dispersion after the last Pleistocene glaciations (Bot et al. 1989a,b, 1991). The moderated divergence observed between C. laetevirens (Dillwyn) Kütz. and C. vagabunda (L.) C. Hoek individuals from North Atlantic and Australia, respectively, was suggested to be a reflex of their eurythermic tolerances, which potentially allowed the dispersion through tropical regions (Bot et al. 1990).

Bakker et al. (1992) defined biogeographic groups of $C$. albida using the ribosomal genes (rDNA) internal transcribed spacers (ITS) sequences, observing that there was a $21 \%$ difference in the ITS sequences when the inter-oceanic individuals were compared. Bakker et al. (1994) studied the Cladophora complex based on the small subunit rRNA gene (SSU rDNA) to verify the evolutionary relationships among species traditionally attributed to Siphonocladales/Cladophorales Orders. They concluded that there is no basis for independent recognition of Cladophorales and Siphonocladales because the first is paraphyletic and the second is polyphyletic.

Bakker et al. (1995) studied the global phylogeography of the cosmopolitan C. vagabunda and concluded that this species represents an intermediary case between the old tropical species, that show a wellmarked vicariance, and cold-temperate to boreal, more recently derived strains that do not present a well-marked vicariance.

Hoek \& Chihara (2000) presented the taxonomic revision of the species of Cladophora from Japan to Russian Far-East, recording the occurrence of 32 taxa and a new approach to the distribution of the species inside the morphological sections was given according to phylogenetic relationships based on SSU rDNA sequences. Further, Hanyuda et al. (2002) observed the phylogenetic relationships in Cladophorales inferred from SSU rDNA sequences and concluded that Cladophora is polyphyletic because many species of this genus are more closely related to species belonging to other genera than are to other Cladophora species.

Recently, Leliaert et al. (2003) inferred the phylogenetic relationships in Cladophorophyceae based on the large subunit rRNA gene (LSU rDNA) sequences and showed that Siphonocladales forms a monophyletic group while Cladophorales remains paraphyletic.

On Brazilian coast, Cladophora vagabunda is widely distributed from Maranhão (North coast) to Rio Grande do Sul States (South coast), according to Oliveira Filho (1977) and Horta et al. (2001). So far, there has been no specific study regarding the phylogenetic relationships among C. vagabunda and other allies in Brazil. Thus, the aim of this study is to verify the relationships among $C$. vagabunda individuals collected from different regions of the Brazilian coast inferred from SSU rDNA sequences.

\section{Material and methods}

Samples - Ten individuals of Cladophora vagabunda and one of C. rupestris (L.) Kütz. were collected from seven locations: three of them in the Northeastern region and the others in the Southeastern region of the Brazilian coast (table 1). The thalli were washed in seawater to remove the excess of sediment and undesirable organisms, briefly dried in absorbent paper, directly transferred to a recipient with silica gel and stored at room temperature.

DNA Extraction - Dehydrated thalli of C. vagabunda (about $40-50 \mathrm{mg}$ ) were macerated in liquid nitrogen with mortar and pestle, until a thin powder was obtained. Total genomic DNA was extracted using the "DNeasy Plant Mini Kit" (Qiagen, Santa Clarita, CA, USA), according to manufacturer's instructions, adding one step of centrifugation before the extract addition to the first purification column. DNA samples were stored at $-20^{\circ} \mathrm{C}$. A DNA aliquot $(5 \mu \mathrm{L})$ was submitted to electrophoresis in $0.7 \%$ agarose gel (Sambrook et al. 1989) to verify quality and quantity of the DNA extracted.

Polymerase chain reaction amplification and sequencing - Primers 18S5' and 18S3'were used for the amplification and sequencing of the SSU rDNA (Sogin 1990, Bird et al. 1992, Oliveira \& Ragan 1994, Milstein \& Oliveira 2005). Polymerase chain reaction (PCR) amplification conditions for a total volume of $50 \mu \mathrm{L}$ were $1 \mathrm{X}$ PCR buffer, $1.5 \mathrm{mM} \mathrm{MgCl}_{2}$, $0.2 \mathrm{mM}$ each dNTP, $0.2 \mu \mathrm{M}$ each primer, around $5 \mathrm{ng}$ of genomic DNA and $1.25 \mathrm{U}$ of Taq DNA polymerase (Invitrogen - Life Technologies, CA, USA). All PCR reactions were performed in a thermocycler "PTC - 150 Mini Cycler" (MJ Research Inc., Maryland) as follows: $94^{\circ} \mathrm{C}$ for $5 \mathrm{~min}, 35$ cycles of $94{ }^{\circ} \mathrm{C}$ for $30 \mathrm{sec}, 55^{\circ} \mathrm{C}$ for $1 \mathrm{~min}$ and $72{ }^{\circ} \mathrm{C}$ for $2 \mathrm{~min}$ and a final extension step at $72^{\circ} \mathrm{C}$ for $7 \mathrm{~min}$. Taq DNA polymerase was added to reactions only when the template was totally denatured (in the first step of $5 \mathrm{~min}$ at $94{ }^{\circ} \mathrm{C}$ ) for a higher specificity of the product to be synthesized. At least three independent PCR reactions were pooled together for each fragment to be sequenced (Baldwin et al. 1995).

PCR products were purified using "MicroSpin ${ }^{\mathrm{TM}} \mathrm{S}-300$ " columns (Amersham Pharmacia Biotech, Piscataway, NJ, USA), according to manufacturer's specifications.

PCR products were directly sequenced using BigDye ${ }^{\mathrm{TM}}$ Terminator Cycle Sequencing Ready Reaction (Applied Biosystems, NJ, USA) by standard methods, on an "ABI PRISM 3100 Genetic Analyzer" (Applied Biosystems). The sequences were assembled to obtain a consensus sequence, using the program Eyeball Sequence Editor (ESEE) version 3.2 (Cabot \& Beckenbach 1989). When site ambiguity 
Table 1: Collection information for Cladophora vagabunda individuals and C. rupestris from Brazil, the SSU rDNA gene size (bp $=$ bases pairs), and GenBank accession number.

\begin{tabular}{|c|c|c|c|c|c|}
\hline Locality & $\begin{array}{l}\text { Collection } \\
\text { date }\end{array}$ & Collector & Observation & $\begin{array}{l}\text { Abbreviation } \\
\text { (GenBank } \\
\text { Accession } n .)\end{array}$ & $\begin{array}{l}\text { SSU } \\
\text { rDNA } \\
\text { (bp) }\end{array}$ \\
\hline \multicolumn{6}{|l|}{ Cladophora vagabunda } \\
\hline $\begin{array}{l}\text { Ponta do Cabo Branco Beach } \\
\text { - João Pessoa (PB) } \\
\left(07^{\circ} 09^{\prime} 48^{\prime \prime} \text { S- } 034^{\circ} 48^{\prime} 36^{\prime \prime} \mathrm{W}\right)\end{array}$ & 7 Oct. 2002 & $\begin{array}{l}\text { L. Gestinari \& } \\
\text { A. Kanagawa }\end{array}$ & $\begin{array}{l}\text { growing on rocks; } \\
\text { intertidal zone }\end{array}$ & $\begin{array}{l}\text { CB1 (FJ715640) } \\
\text { CB2 (FJ715641) }\end{array}$ & $\begin{array}{l}1783 \\
1781\end{array}$ \\
\hline $\begin{array}{l}\text { Boa Viagem Beach - Recife (PE) } \\
\left(08^{\circ} 07^{\prime} 51,9^{\prime \prime} \text { S- } 034^{\circ} 53^{\prime} 55,32^{\prime \prime} \mathrm{W}\right)\end{array}$ & $\begin{array}{l}9 \text { Aug. } 2002 \\
21 \text { Sep. } 2002\end{array}$ & $\begin{array}{l}\text { L. Gestinari \& } \\
\text { J. Torres }\end{array}$ & $\begin{array}{l}\text { growing on the } \\
\text { fringe of sandstone } \\
\text { reef; infralittoral }\end{array}$ & $\begin{array}{l}\text { BV1 (FJ715642) } \\
\text { BV2 (FJ715643) }\end{array}$ & $\begin{array}{l}1781 \\
1783\end{array}$ \\
\hline $\begin{array}{l}\text { Sereias Beach - Maceió (AL) } \\
\left(09^{\circ} 333^{\prime} 53,3^{\prime \prime} \mathrm{S}-035^{\circ} 38^{\prime} 43,9^{\prime \prime} \mathrm{W}\right)\end{array}$ & 04 Oct. 2002 & $\begin{array}{l}\text { L. Gestinari \& } \\
\text { E. Guedes }\end{array}$ & $\begin{array}{l}\text { growing on the } \\
\text { fringe of sandstone } \\
\text { reef; infralittoral }\end{array}$ & $\begin{array}{l}\text { SER1 (FJ715644) } \\
\text { SER2 (FJ715645) }\end{array}$ & $\begin{array}{l}1782 \\
1781\end{array}$ \\
\hline $\begin{array}{l}\text { Portocel Beach - Aracruz (ES) } \\
\left(19^{\circ} 53^{\prime} 18^{\prime \prime} \mathrm{S}-040^{\circ} 05^{\prime} 30^{\prime \prime} \mathrm{W}\right)\end{array}$ & 29 Jun. 2003 & C. Nassar & $\begin{array}{l}\text { growing on rocks; } \\
\text { intertidal zone }\end{array}$ & POR (FJ715646) & 1781 \\
\hline $\begin{array}{l}\text { Prainha Beach - Arraial do } \\
\text { Cabo (RJ) } \\
\left(22^{\circ} 57^{\prime} 30^{\prime} \text { S- } 042^{\circ} 01^{\prime} 30^{\prime} \mathrm{W}\right)\end{array}$ & 1 Aug. 2003 & $\begin{array}{l}\text { L. Gestinari \& } \\
\text { J. Torres }\end{array}$ & $\begin{array}{l}\text { growing on rocks; } \\
\text { intertidal zone }\end{array}$ & PRA (FJ715647) & 1781 \\
\hline $\begin{array}{l}\text { Conchas Beach - Cabo Frio (RJ) } \\
\left(22^{\circ} 53^{\prime} 00^{\prime \prime} \mathrm{S}-042^{\circ} 01^{\prime} 30^{\prime \prime} \mathrm{W}\right)\end{array}$ & 1 Aug. 2003 & $\begin{array}{l}\text { L. Gestinari \& } \\
\text { J. Torres }\end{array}$ & $\begin{array}{l}\text { growing on rocks; } \\
\text { intertidal zone }\end{array}$ & CON (FJ715648) & 1781 \\
\hline $\begin{array}{l}\text { Boa Viagem Island - Niterói (RJ) } \\
\left(23^{\circ} 54^{\prime} 36^{\prime \prime} \mathrm{S}-043^{\circ} 07^{\prime} 48^{\prime \prime} \mathrm{W}\right)\end{array}$ & 16 Jun. 2003 & $\begin{array}{l}\text { L. Gestinari \& } \\
\text { J. Torres }\end{array}$ & $\begin{array}{l}\text { growing on rocks; } \\
\text { intertidal zone }\end{array}$ & IBV (FJ715649) & 1781 \\
\hline \multicolumn{6}{|l|}{ Cladophora rupestris } \\
\hline $\begin{array}{l}\text { Ponta do Cabo Branco Beach } \\
\text { - João Pessoa (PB) } \\
\left(07^{\circ} 09^{\prime} 48^{\prime} \text { ' S- } 034^{\circ} 48^{\prime} 36^{\prime \prime} \mathrm{W}\right)\end{array}$ & 7 Oct. 2002 & $\begin{array}{l}\text { L. Gestinari \& } \\
\text { A. Kanagawa }\end{array}$ & $\begin{array}{l}\text { growing on rocks; } \\
\text { intertidal zone }\end{array}$ & RUP (FJ715639) & $1634^{1}$ \\
\hline
\end{tabular}

${ }^{1}$ partial SSU rDNA sequence.

was observed, a careful analysis was performed on the chromatograms to confirm the correct nucleotides on those sites. If the confirmation was not possible, new sequences were generated. Full gene sequence was obtained from both strands, except for sample RUP (table 1), for which only partial sequence was obtained (1634 bp).

Matrix - Consensus sequences obtained for the SSU rDNA from each individual analyzed were aligned using ClustalW in BioEdit program (Hall 1999) and were manually inspected. SSU rDNA sequences from other Cladophorales species were imported from GenBank (see figure 1 for accession numbers) and included in the alignments. The sequences from $C$. horii C. Hoek \& Chihara and C. conchopheria Sakai were chosen as outgroups. Sequences corresponding to amplification primers $18 \mathrm{~S} 5$ ' and $18 \mathrm{~S} 3$ ' and variable regions, which could not be unambiguously aligned, were removed from the alignments, yielding a final matrix of 29 taxa sequences with 1558 positions.

Phylogenetic trees construction - All phylogenetics analyses were performed with PAUP $4.0 \mathrm{~b} 8$ (Swofford 2000). An appropriate evolution model was selected using Modeltest 3.06 (Posada \& Crandall 1998). The selected model estimated from our data was Tamura \& Nei (1993) with equal base frequencies. Base substitution model was determined as $[\mathrm{A} \leftrightarrow \mathrm{C}, \mathrm{A} \leftrightarrow \mathrm{T}$, $\mathrm{C} \leftrightarrow \mathrm{G}, \mathrm{G} \leftrightarrow \mathrm{T}]=1.0000,[\mathrm{~A} \leftrightarrow \mathrm{G}]=1.8236$ and $[\mathrm{C} \leftrightarrow \mathrm{T}]$ $=5.1336$. The proportion of invariable sites considered was 0.7620 and the gamma distribution rate parameter was 0.5866 for rate heterogeneity on variable sites.

Trees were inferred using three different methods. For the distance method, a neighbor-joining (NJ) tree (Saitou \& Nei 1987) was built with Tamura \& Nei (1993) substitution model. A maximum parsimony (MP) tree was inferred by 


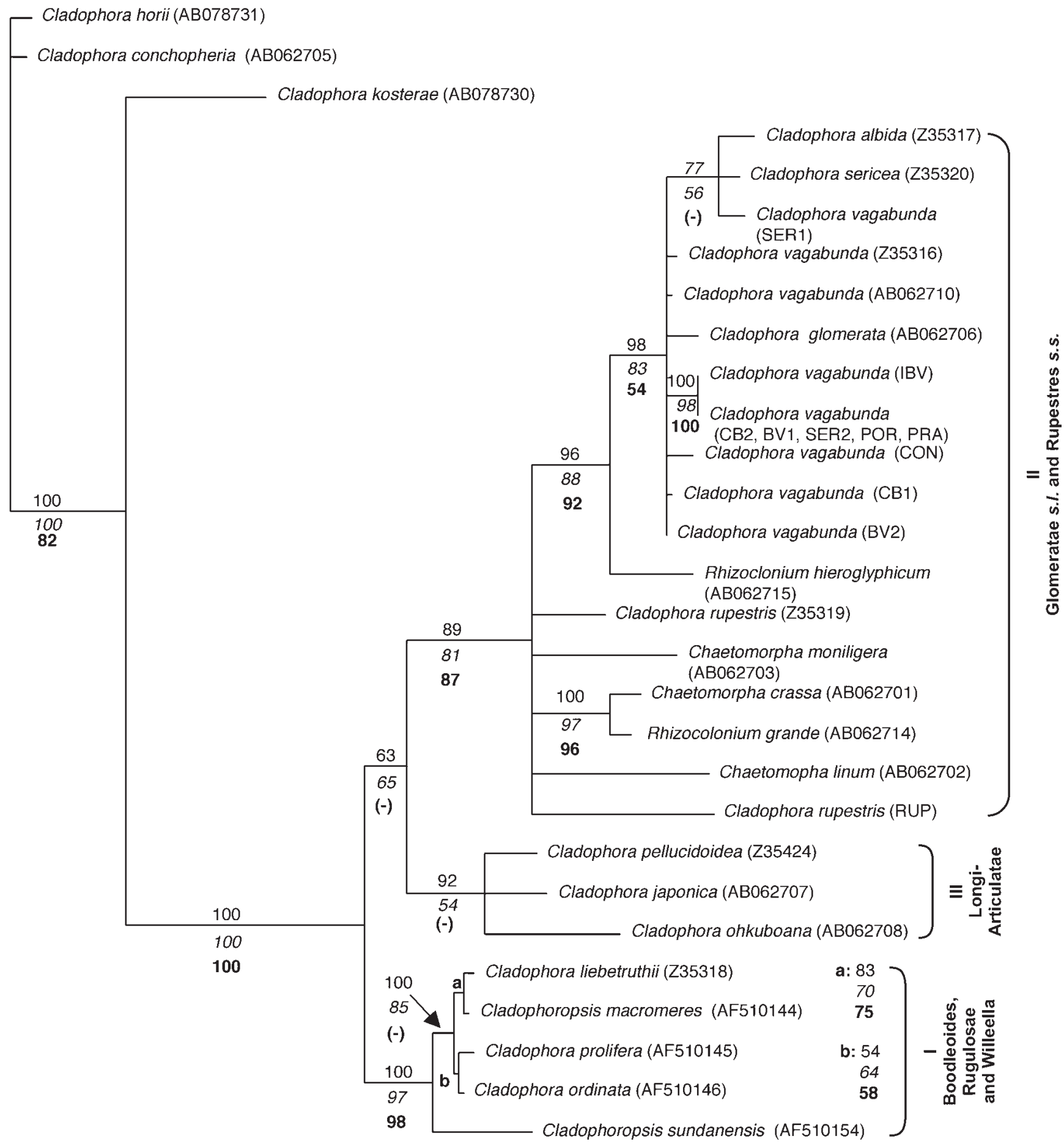

10 changes

Figure 1. Maximum parsimony consensus tree based on SSU rDNA. Bootstrap values for the different analyses are plotted on the branches: neighbor joining (first line, normal typeface) and maximum parsimony (second line, italic typeface) were performed for 2000 replicates; maximum likelihood (third line, bold typeface) was performed for 100 replicates. An arrow or a letter $(a, b)$ indicate these values where they do not fit. (-) indicates no support. Within brackets there is the GenBank accession number or abbreviation for the Brazilian collections (see table 1). I - III are the subgroup formed with the respective sections. 
heuristic search, with starting trees obtained by stepwise addition, with random sequence addition ( 10 replicates) using the tree bisection-reconnection (TBR) branch-swapping algorithm. The number of parsimony-informative sites was 138. In both NJ and MP trees, gaps were treated as missing data and all sites were weighted equally. Bootstrap analyses (Felsenstein 1985) were performed with 2000 replicates for the methods described above.

Maximum likelihood (ML) analysis was performed with heuristic search using TBR algorithm, with starting trees obtained via stepwise addition as described for the MP tree. Other specifications were estimated with Modeltest as described above. Bootstrap re-sampling was done for 100 replicates due to computational limitations.

For all analyses, bootstrap values were considered low up to $70 \%$, moderate from $71 \%$ to $90 \%$, and high above $90 \%$.

\section{Results}

The complete SSU rDNA was sequenced for 10 individuals identified as Cladophora vagabunda collected along the coast of Brazil. The size of the SSU rDNA varied from 1781 to $1783 \mathrm{bp}$ (table 1). For $C$. rupestris only a partial SSU rDNA sequence of $1634 \mathrm{bp}$ was obtained (the 3' end of the gene is missing). Sequence identity for the SSU rDNA varied from $98.9 \%$ to $100 \%$ for the Brazilian C. vagabunda individuals (table 2). Five individuals presented $100 \%$ identity for the SSU rDNA sequences (CB2; BV1; SER2; POR; and PRA). Comparing the Brazilian C. vagabunda individuals with the other SSU rDNA available in GenBank, the identities varied from $98.3 \%$ to $99.1 \%$ to C. vagabunda (Z35316) from France (Bakker et al. 1994), and from $99.1 \%$ to $99.7 \%$ to $C$. vagabunda (AB062710) from Japan (Hanyuda et al. 2002). The sequence identity of the Brazilian C. vagabunda individuals to C. albida (Z35316) varied from $98.0 \%$ to $98.4 \%$ and to $C$. sericea (Z34320) from $98.0 \%$ to $98.6 \%$. On the other hand, C. rupestris from Brazil showed only $96.9 \%$ of identity to C. rupestris (Z35319) from France and from $96.5 \%$ to $96.8 \%$ of identity to the Brazilian C. vagabunda individuals.

Phylogenetic trees obtained from three different inference methods were very similar and only minor changes in topology were observed at branches with low bootstrap values. Therefore, only the maximum parsimony (MP) tree is presented in figure 1 with the bootstrap values of the other analyses plotted in the common branches.

Species of Cladophoraceae and Siphonocladaceae (Order Cladophorales sensu Wynne 2005) were included in the phylogenetic analyses. Cladophora horii (section Rugulosae) and C. conchopheria (section Glomeratae

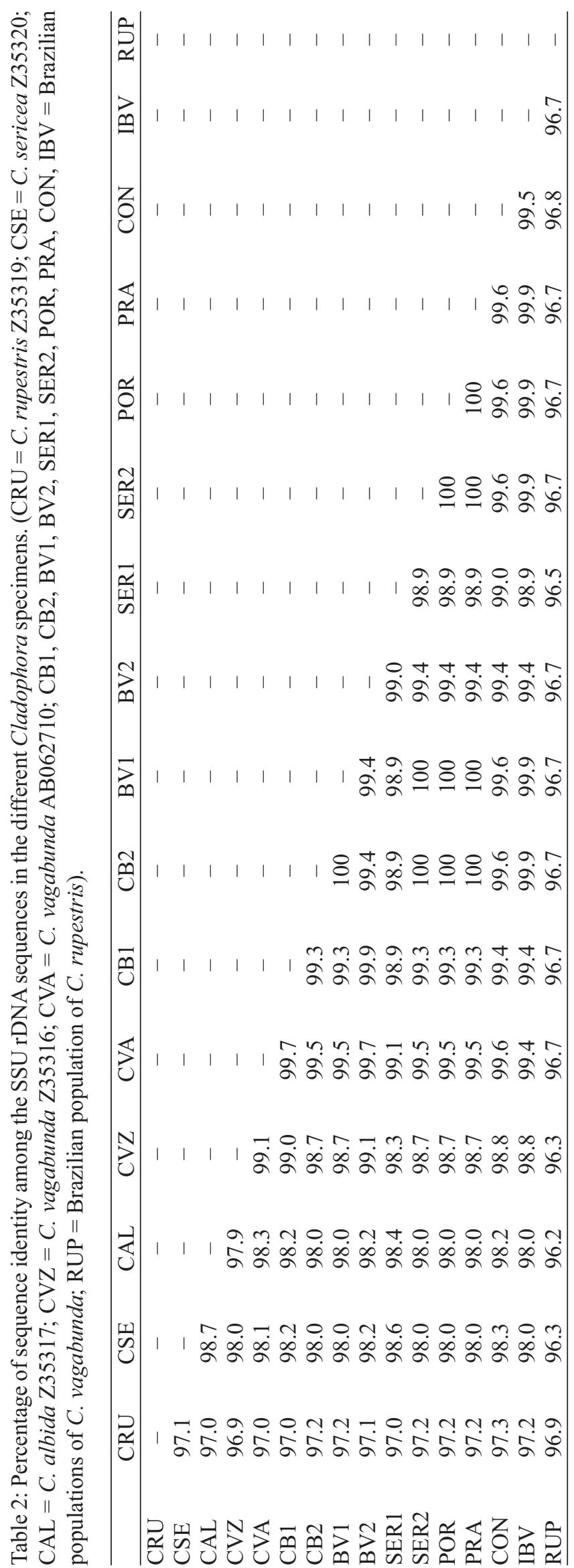


s.l.) were chosen as outgroup taxa. Cladophora kosterae C. Hoek, a species that belongs to the section Basicladia, appeared basally rooting the remaining taxa, which grouped in all analyses with strong bootstrap support.

In all phylogenetic analyses two main groups were formed, presenting bootstrap support (figure 1): group I composed of Cladophora and Cladophoropsis species; and group II composed of Cladophora, Chaetomorpha and Rhizoclonium species. A third group, basal to group II, was formed in the MP tree, but with no support from the other inference methods, it is composed of three Cladophora species of the section Longi-articulatae: C. pellucidoidea C. Hoek, C. japonica Yamada and C. ohkuboana Holmes (group III).

Group I, with high bootstrap support, was formed by three different sections of Cladophora with very distinct morphologies: Boodleoides (C. liebetruthii Grunow), Rugulosae [C. prolifera (Roth) Kütz.] and Willeella [C. ordinata (B prgesen) C. Hoek], and by two species of the Siphonocladaceae family: Cladophoropsis macromeres W.R. Taylor and C. sundanensis Reinbold.

In all phylogenetic analyses group II presented moderate to high bootstrap support, including all species of the sections Glomeratae s.l. and Rupestres s.s. and also species of Chaetomorpha and Rhizoclonium. Within this group II, Rhizoclonium hieroglyphicum (C. Agardh) Kütz is rooting, a monophyletic group including C. vagabunda, C. albida, C. sericea and the freshwater taxa C. glomerata (L.) Kütz. This clade, with moderate to high bootstrap support, includes all the $C$. vagabunda individuals from Brazil, Japan and France. The Brazilian individual SER1 grouped together with $C$. albida (Roscoff, France) and C. sericea (Roscoff, France).

Both C. rupestris (L) Kütz, from France (Z35319) and from Brazil are in a basal polytomy of group II which also includes a second Rhizoclonium species (R. grande B prgesen) that groups with high bootstrap support to Chaetomorpha crassa (C. Agardh) Kütz, as well as two species of Chaetomorpha [C. moniligera Kjellman and C. linum (Müller) Kütz.].

\section{Discussion}

In this paper we present the first molecular phylogenetic analyses, which include SSU rDNA sequences from ten individuals identified as Cladophora vagabunda and one as $C$. rupestris from Brazil. Based on the results presented in this paper and previous papers by other authors (Bakker et al. 1994, Hanyuda et al. 2002) the genus Cladophora is clearly paraphyletic, as it includes representatives from at least three other genera,
Cladophoropsis, Rhizoclonium and Chaetomorpha. Therefore, an extensive taxonomic review, using different types of data (e.g. morphology and molecular markers), is necessary to clarify and rearrange the taxonomy of those genera.

The section Glomeratae sensu lato (C. vagabunda, C. albida, C. sericea, and C. glomerata) appears as a monophyletic group in the phylogenetic analyses carried out in this study and also in the studies of Bakker et al. (1994) and Hanyuda et al. (2002). Thalli architecture of the members of the section Glomeratae sensu lato is relatively heterogeneous and varies from strict acropetal to irregular, being the growth by apical or intercalary cell divisions (Hoek \& Chihara 2000).

The species $C$. vagabunda is paraphyletic as it includes other species of the section Glomeratae sensu lato (C. albida, C. sericea, and C. glomerata), corroborating previous results by Hanyuda et al. (2002), and therefore, the $C$. vagabunda complex needs to be taxonomically reviewed. Due to the relatively high amount of variation in the SSU rDNA in the $C$. vagabunda complex, but considering the monophyly of the complex with other closely related species, we suggest that a new genus is erected to accommodate the different species in this complex

The morphological characteristics presented by the Brazilian individuals of C. vagabunda corroborate, partly, the phylogenetic relationships presented in this study (Gestinari 2004). Although, the individual SER1, collected from Sereias Beach (AL), presents similar morphological characteristics to the representatives of the other Brazilian individuals of C. vagabunda, it is grouped with C. albida and $C$. sericea from France. Probably, SER1 is a $C$. dalmatica, a species strictly related to $C$. vagabunda, not only morphologically, but also ecologically; the differences in $C$. dalmatica are the diameter of the apical cells (38 $\pm 12 \mu \mathrm{m}$ diam.), terminal branches $(47 \pm 14 \mu \mathrm{m}$ diam.) and main branch $(102 \pm 35 \mu \mathrm{m}$ diam.), which are thinner than in C. vagabunda $(70 \pm 19 \mu \mathrm{m}$ diam., $83 \pm 22 \mu \mathrm{m}$ diam. and $200 \pm 29 \mu \mathrm{m}$ diam., respectively) (Gestinari 2004, Hoek 1982, Hoek \& Chihara 2000). Cladophora dalmatica, as $C$. vagabunda, belongs to the "amphiatlantic tropical-to-temperate distribution group", occurring from the tropics on both sides of the Atlantic Ocean to about $45^{\circ} \mathrm{N}$ latitude along American Atlantic coasts and almost $57^{\circ} \mathrm{N}$ latitude along European Atlantic coasts, while $C$. vagabunda occurs from the tropics to about $50^{\circ} \mathrm{N}$ latitude along American Atlantic coasts and almost $60^{\circ} \mathrm{N}$ latitude along European shores (Hoek 1979).

The Brazilian populations of C. vagabunda (IBV and the individuals that have identical SSU rDNA: CB2, 
BV1, SER2, POR and PRA) collected from Rio de Janeiro (Southeast) to Paraiba (Northeast) States formed a branch with high bootstrap support in all analyses. This branch presented individuals with highly similar morphological characteristics, with more delicate thalli, bearing lesser branches and with cells dimensions slightly smaller than the representatives from the populations $\mathrm{CON}, \mathrm{CB} 1$ and BV2 which presented more rigid thalli, a higher number of ramifications and similar cell size (Gestinari 2004). However, individuals CB2, BV1 and SER2 were collected from reef areas with oligotrophic waters, while individuals IBV, PRA and POR were collected on rocky shores exposed to the wave action and also under strong influence of nitrogenous compounds from natural or artificial origin. This indicates that individuals with identical SSU rDNA and similar morphologies can be found in quite different types of environments. The specimens of CB1 and BV2, which have divergent SSU rDNA sequences, proceeding from relatively close locations, with very similar environmental conditions (temperature, salinity), were both collected in the intertidal region from the sandstone reef, growing in places with moderate exposition to the waves action. The specimen CON was collected from rocky shores exposed to the wave action and under strong influence of nitrogenous compounds from natural origin.

Many authors have mentioned that $C$. vagabunda presents an extremely plastic morphology, highly influenced by environmental factors as well as the age of the thallus (Hoek 1963, 1982, Dodds \& Gudder 1992, Hoek et al. 1995). The slight differences observed among these populations, probably, could be related to the morphological plasticity and environmental conditions of the different collection sites, since the morphological characteristics agree with those mentioned in the literature for this species (Hoek 1963, 1982, Lawson \& John 1982, Hoek \& Womersley 1984, Hoek \& Chihara 2000).

According to Hoek \& Chihara (2000), C. rupestris is the type species within the section Rupestres s.s. The Brazilian C. rupestris does not group with C. rupestris from France, both are in a polytomy including Chaetomorpha species. The proximity of $C$. rupestris with the genus Chaetomorpha has been reported in previous papers (Bakker et al. 1994, Hanyuda et al. 2002). Cladophora rupestris grouped with Chaetomorpha species in the ML analysis inferred from LSU rDNA carried out by Leliaert et al. (2003) indicating that, as suggested by Hoek (1982), Chaetomorpha could be considered as a reduced form and not as a primitive sister genus of Cladophora.

In this study, Section Longi-articulatae comprised by C. pellucidoidea, C. japonica and C. ohkuboana formed a monophyletic group, not closely related to C. prolifera. Similar results were also observed in Bakker et al. (1994) SSU rDNA phylogeny, in which species of the section Rugulosae, such as C. prolifera, stand clearly apart from the section Longi-articulatae, corroborating the morphological differences between these two sections: branch insertion and structure and disposition of the rhizoids (Hoek 1982, Hoek \& Chihara 2000).

The inclusion of sequences from Brazilian individuals of Cladophora reinforces the need of taxonomical revision for the genus and for the complex C. vagabunda. To have a better understanding of the monophyly and of the divergence among species and isolates of the Cladophora vagabunda complex it will be necessary to obtain sequences for other molecular markers and from a broader geographic sampling.

Acknowledgements - The authors would like to thank to Pronex-Facepe, CNPq and Fapesp for the financial support; $\mathrm{CNPq}$ for the scholarships, Silvia Blanco and Rosário Petti for their technical assistance.

\section{References}

BAKKER, F.T., OLSEN, J.L., STAM, W.T. \& HOEK, C. VAN DEN. 1992. Nuclear ribosomal DNA internal transcribed spacer regions (ITS1 and ITS2) define discrete biogeographic groups in Cladophora albida (Chlorophyta). Journal of Phycology 28:839-845.

BAKKER, F.T., OLSEN, J.L., STAM, W.T. \& HOEK, C. VAN DEN. 1994. The Cladophora complex (Chlorophyta): new views based on 18S rRNA gene sequences. Molecular Phylogenetics and Evolution 2:365-382.

BAKKER, F.T., OLSEN, J.L. \& STAM, W.T. 1995. Global phytogeography in the cosmopolitan species Cladophora vagabunda (Chlorophyta) based on nuclear rDNA internal transcribed spacer sequences. European Journal of Phycology 30:197-208.

BALDWIN, B.G., SANDERSON, M.J., PORTER, J.M., WOJCIECHOWISK, M.F., CAMPBELL, C.S. \& DONOGHUE, M.J. 1995. The ITS region of nuclear ribosomal DNA: a valuable source of evidence of Angiosperm phylogeny. Annals of the Missouri Botanical Garden 82:247-277.

BIRD, C.J., RICE, E.L., MURPHY, C.A. \& RAGAN, M.A. 1992. Phylogenetic relationships in the Gracilariales (Rhodophyta) as determined by $18 \mathrm{~S}$ rDNA sequences. Phycologia 31:510-522.

BOT, P.V.M., HOLTON, R., STAM, W.T. \& HOEK, C. VAN DEN. 1989a. Molecular divergence between NorthAtlantic and Indo-West Pacific Cladophora albida (Cladophorales, Chlorophyta) isolates as indicated by DNA-DNA hybridization. Marine Biology 28:159-168. 
BOT, P.V.M., STAM, W.T., BOELE-BOS, S.A., HOEK, C. VAN DEN \& DELDEN, W. VAN. 1989b. Biogeographic and phylogenetic studies in three North Atlantic species of Cladophora (Cladophorales, Chlorophyta), using DNA-DNA hybridization. Phycologia 28:159-168.

BOT, P.V.M., STAM, W.T. \& HOEK, C. VAN DEN. 1990. Genotypic relations between geographic isolates of Cladophora laetevirens and C. vagabunda. Botanica Marina 33:441-446.

BOT, P.V.M., BRUSSAARD, C.P.D., STAM, W.T. \& HOEK, C. VAN DEN 1991. Evolutionary relationships between four species of Cladophora (Cladophorales, Chlorophyta) based on DNA-DNA hybridization. Journal of Phycology 27:617-623.

CABOT, E.L. \& BECKENBACH, A.T. 1989. Simultaneous editing of multiple nuclei acid and protein sequences with ESEE. Computer Applied Bioscience 5:233-234.

DODDS, W.K. \& GUDDER, D.A. 1992. The ecology of Cladophora - review. Journal of Phycology 28:415427.

FELSENSTEIN, J. 1985. Confidence limits on phylogenies: an approaching using bootstrap. Evolution 39:783791.

GESTINARI, L.M.S. 2004. Taxonomia e distribuição do gênero Cladophora Kützing (Cladophorales, Chlorophyta) no litoral brasileiro. Thesis (Doutorado), Universidade Federal Rural de Pernambuco, Recife.

HALL, T.A. 1999. BioEdit: a user-friendly biological sequence alignment editor and analysis program for Windows 95/98/NT. Nucleic Acids Symposium Series 48:95-98.

HANYUDA, T., WAKANA, I., ARAI, S., MIYAJI, K., WATANO, Y. \& UEDA, K. 2002. Phylogenetic relationship within Cladophorales (Chlorophyta) inferred from 18S rRNA gene sequences, with special reference to Aegagroplia linnaei. Journal of Phycology 38:564-571.

HOEK, C. VAN DEN. 1963. Revision of the European species of Cladophora. Brill, Leiden.

HOEK, C. VAN DEN. 1979. The phytogeography of Cladophora (Chlorophyceae) in the northern Atlantic Ocean, in comparison to that of other benthic algal species. Helgolander Wissenschaftliche Meeresuntersuchungen 32:374-393.

HOEK, C. VAN DEN. 1982. A taxonomic revision of the American species of Cladophora (Chlorophyceae) in the North Atlantic Ocean and their geographic distribution. North-Holland Publishing Company, Amsterdam.

HOEK, C. VAN DEN \& WOMERSLEY, H.B.S. 1984. The marine benthic flora of Southern Australia. Part I. Chlorophyta. D. J. Woolman, Adelaide.

HOEK, C. VAN DEN, MANN, D.G. \& JAHNS, H.M. 1995. Algae - an introduction to Phycology. Cambridge, Cambridge University Press.
HOEK, C. VAN DEN \& CHIHARA, M. 2000. A taxonomic revision of the marine species of Cladophora (Chlorophyta) along the coasts of Japan and Russian Far-East. National Science Museum, Tokyo.

HORTA, P.A., AMANCIO, C.E., COIMBRA, C.S. \& OLIVEIRA, E.C. 2001. Considerações sobre a distribuição e origem da flora de macroalgas marinhas brasileiras. Hoehnea 28:243-265.

LAWSON, G.W. \& JOHN, D.M. 1982. The marine algae and coastal environment of tropical West Africa. Nova Hedwigia 70:1-455.

LELIAERT, F., ROUSSEAU, F., REVIERS, B \& COPPEJANS, E. 2003. Phylogeny of the Cladophorophyceae (Chlorophyta) inferred from partial LSU rRNA gene sequences: is the recognition of a separate order Siphonocladades justified? European Journal of Phycology 38:233-246

MILSTEIN, D. \& OLIVEIRA, M.C. 2005. Molecular phylogeny of Bangiales (Rhodophyta) based on small subunit rDNA sequencing: emphasis on Brazilian Porphyra species. Phycologia 44:212-221.

OLIVEIRA FILHO, E.C. 1977. Algas marinhas bentônicas do Brasil. Thesis (Livre Docência). University of São Paulo, São Paulo.

OLIVEIRA, M.C. \& RAGAN, M.A. 1994. Variant forms of a group I intron in nuclear small-subunit rRNA genes of the marine red alga Porphyra spiralis var. amplifolia. Molecular Biology and Evolution 11:195-207.

POSADA, D. \& CRANDALL, K.A. 1998. MODELTEST: testing the model of DNA substitution. Bioinformatics 14:817-818.

SAITOU, N. \& NEI, M. 1987. The neighbor-joining method: a new method for reconstructing phylogenetic trees. Molecular Biology and Evolution 4:406-425.

SAMBROOK, J., FRITSCH, E.F. \& MANIATIS, T. 1989. Molecular cloning: a laboratory manual. $2^{\text {nd }}$ edition. Cold Spring Harbour Laboratories Press. New York, $3 \mathrm{v}$.

SOGIN, M.L. 1990. Amplification of ribosomal RNA genes for molecular evolution studies. In PCR Protocols. A guide to methods and applications (M.A. Innes, D.H. Gelfand, J.J. Sninsky \& T.J. White, eds.). Academic Press, San Diego, p.307-314.

SOGIN, M.L., HINKLE, G. \& LEIPE, D.D. 1993. Universal tree of life. Nature 362:795.

SWOFFORD, D.L. 2000 - PAUP*. Phylogenetic analysis using parsimony ( $*$ and other methods). Version 4. Sunderland, Sinauer Associates, Massachusetts.

TAMURA, K. \& NEI, M. 1993. Estimation of the number of nucleotide substitutions in the control region of mitochondrial DNA in humans and chimpanzees. Molecular Biology and Evolution 10:512-526.

WYNNE, M.J. 2005. A checklist of benthic marine algae of the tropical and subtropical western Atlantic: second revision. Nova Hedwigia 129:1-152. 